BACKGROUND: Serum neopterin concentrations rise during activation of the cellular immune system. It is suggested that neopterin interacts with cellular redox mechanisms. This induces oxidative stress, which inhibits intracellular $\mathrm{Ca}^{2+}$ transients in various cell types. In type II alveolar epithelial cells, $\mathrm{Ca}^{2+}$ increase is considered involved in the exocytosis of surfactants. This exocytosis is disturbed during inflammation.

Aims : To clarify whether neopterin affects adenosine triphosphate (ATP)-induced $\mathrm{Ca}^{2+}$ transients in an alveolar epithelial cell line (L2).

Metbods : $\mathrm{Ca}^{2+}$ transients were detected as fura-2 fluorescence by an image analysis system.

Results : Cells were exposed for $100 \mathrm{sec}$ to ATP ( $1 \mu \mathrm{M}$, repeated four times). The first application of ATP induced an increase of the fluorescence ratio by approximately $100 \%$, while the following stimulations resulted in smaller transients. In a second set of experiments, L2 cells were exposed to ATP or ATP + neopterin (100 nM), alternately. Simultaneous application of neopterin inhibited $\mathrm{Ca}^{2+}$ transients almost completely.

Conclusions: Inhibition of $\mathrm{Ca}^{2+}$ transients by neopterin may lead to suppressed exocytosis of surfactant proteins in alveolar epithelial cells. This might contribute to the deterioration of pulmonary functions in the course of inflammatory processes.

Key words: Neopterin, Calcium, Alveolar epithelium, Inflammation

\section{Neopterin inhibits ATP-induced calcium release in alveolar epithelial cells in vitro}

\author{
Georg Hoffmann ${ }^{1, C A}$, Frank Gollnick ${ }^{2}$ and \\ Rainer Meyer $^{2}$
}

1Department of Physiology I, and ${ }^{2}$ Department of Physiology II, University of Bonn, Nussallee 11, 53111 Bonn, Germany

\footnotetext{
${ }^{\mathrm{CA}}$ Corresponding author:

Tel: +49228732337

Fax: +49228732408

E-mail: umvb01@uni-bonn.de
}

\section{Introduction}

Neopterin is a pyrazino pyrimidine compound that is biosynthesized from guanosine triphosphate in the pathway leading to tetrahydrobiopterin. Due to a low constitutive activity of the second enzyme within this pathway, 6-pyrovoyl tetrahydropterin synthase, human monocytes/macrophages produce and release large amounts of neopterin following activation with T-lymphocyte-derived interferon- $\gamma$. Thus, serum and urinary neopterin levels serve as an indicator in patients with diseases associated with an increased activity of the cellular immune system (e.g. viral and bacterial infections, acute graft rejections, and acquired immune deficiency syndrome). In the lung, correlations between serum levels of neopterin and the severity of disease have been demonstrated for inflammatory disorders such as sarcoidosis, lung cancer, tuberculosis, and sepsis. ${ }^{1}$ Apart from being a clinical marker for these conditions, neopterin seems to exhibit distinct biochemical functions via interactions with cellular redox mechanisms and the promotion of oxidative stress. Therefore, neopterin may play a role as a modulator during host defence reactions. Neopterin was shown to enhance chlor-
amine-T-mediated and $\mathrm{H}_{2} \mathrm{O}_{2}$-mediated chemiluminescence as well as toxicity against bacteria,${ }^{2}$ to activate the transcripiton factor NF- $\mathrm{B}$ with a subsequent stimulation of inducible nitric oxide synthase gene expression in vascular smooth muscle cells, ${ }^{3}$ or to induce apoptosis in different cell lines. ${ }^{4}$ Since these events are mediated by oxidative stress, one may speculate that neopterin enhances oxidative mechanisms, either by stressing pro-oxidative mediators or by the consumption of anti-oxidative counter-regulatory means, or both.

Surfactant proteins are stored in and released from intracellular lamellar bodies by alveolar type II epithelial cells. The importance of an increase of cytoplasmic $\mathrm{Ca}^{2+}\left(\left[\mathrm{Ca}^{2+}\right]_{i}\right)$ for surfactant release is supported by studies using $\mathrm{Ca}^{2+}$ ionophores and by the observation that surfactant release by $\beta$-adrenergic and purinergic stimulation is accompanied by an elevation in intracellular $\mathrm{Ca}^{2+} .5,6$ It has been demonstrated that oxidative stress inhibits intracellular $\mathrm{Ca}^{2+}$ transients in various cell types; for example, in retinal cells $^{7}$ or in ventricular cardiomyocytes. ${ }^{8}$ However, the influence of oxidative stress on $\left[\mathrm{Ca}^{2+}\right]_{i}$ has not yet been investigated in lung epithelial cells. Disturbances of cellular $\mathrm{Ca}^{2+}$ homeostasis by oxidative 
stress in type II alveolar epithelial cells might inhibit surfactant release and may thereby contribute to pulmonary dysfunctions commonly observed in the course of inflammatory diseases.

In the present study, we investigate the effects of neopterin on adenosine triphosphate (ATP)-induced $\mathrm{Ca}^{2+}$ transients in a type II-like alveolar epithelial cell line (L2). Within type II-like cells, ATP is a potent stimulus of $\left[\mathrm{Ca}^{2+}\right]_{i}$ due to intracellular $\mathrm{Ca}^{2+}$ release. 9,10 Neopterin, the hypothetical inducer of oxidative stress, was added to look for its inhibitory potential on ATP-induced $\mathrm{Ca}^{2+}$ transients.

\section{Materials and methods}

\section{Culture of $L 2$ cells}

The lung epithelial cell line, L2 (adult female Lewis strain rat), was purchased from the American Type Culture Collection, No. CCL-149 (Rockville, MD, USA). Cells were grown in $25 \mathrm{~cm}^{2}$ culture flasks in Dulbecco's modified Eagle's medium (DMEM) containing 5\% fetal calf serum (FCS), L-glutamine (2 mM), and penicillin-streptomycin $(100 \mathrm{U} / \mathrm{ml}-100 \mu \mathrm{g} / \mathrm{ml})$. Every 5 th day, confluent cultures were passaged by incubation $\left(10 \mathrm{~min}\right.$ at $\left.37^{\circ} \mathrm{C}\right)$ in phosphate-buffered saline solution containing $0.05 \%$ trypsin and $0.02 \%$ ethylenediamine tetraacetic acid (EDTA). For experiments, cells were seeded $\left(10^{4}\right.$ cells $\left./ \mathrm{cm}^{2}\right)$ into 24 -well plates (diameter, $35 \mathrm{~mm} /$ dish; media volume, $1 \mathrm{ml}$ ) containing coverslips for fluorescence microscopy and were grown to confluence. Passages 45-55 of subcultured cells were used for the present experiments.

\section{Fura-2 experiments}

L2 cells were incubated with $4 \mu \mathrm{M}$ Fura- 2 for $15 \mathrm{~min}$ and were mounted in a perfusion chamber that allowed complete changing of the external medium within $1 \mathrm{~min}$, and they were investigated at $37^{\circ} \mathrm{C}$ in permanent perfusion. Fura-2 fluorescence was recorded using a Zeiss IM 35 microscope with a Zeiss Ultrafluor 100 objective (Carl Zeiss, Jena, Germany). The excitation pathway consisted of a Leitz xenon lamp $(150 \mathrm{~W})$ and a filter wheel with two excitation filters $(340 \mathrm{~nm}, 380 \mathrm{~nm}, 10 \mathrm{~nm}$ bandwidth). The emitted light was passed through a filter combination (Zeiss LP 429 plus Schott BG39). TV images were acquired by an intensified video camera, C $2400-77 \mathrm{H}$, with an amplifier unit, C 2400-80 (Hamamatsu Photonics, Hamamatsu City, Japan) and passed to a Hamamatsu Interactive Calcium Monitoring System. Two subsequent TV images were recorded at $340 \mathrm{~nm}$ excitation and averaged online. The resulting image was stored in a personal computer. Then the filter was changed to $380 \mathrm{~nm}$ within $40 \mathrm{msec}$ and the same

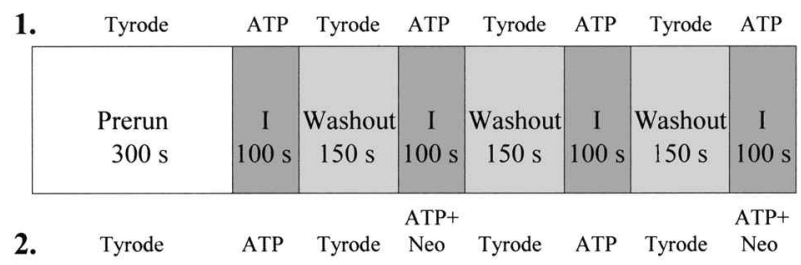

FIG. 1. Schedule for the first and second experimental protocols (I, incubation; Neo, neopterin).

procedure as described for $340 \mathrm{~nm}$ excitation was repeated. The next image pair was taken after $10 \mathrm{sec}$. Parameters for image acquisition were $256 \times 256$ pixels/image with 256 gray levels, and each digitized image was corrected for the camera dark current. Images of cells were discriminated at their borders from the extracellular space by transforming all gray values below a threshold value to zero. In a second step, the gray-value distribution of one selected ratio image was exhibited as a histogram to chose the borders for an interactive gray-value scaling. All ratio images were calculated pixel by pixel according to the chosen gray-value scaling and documented in pseudocolor mode.

Neopterin excited with UV light acts as a fluorescent dye (excitation maximum, $353 \mathrm{~nm}$; emission, $438 \mathrm{~nm}$ ). To prevent overlap between Fura-2 and neopterin fluorescence emission, the neopterin concentration was kept below the level of detectable fluorescence.

\section{Experimental set-up}

As shown in Figure 1, each experiment started with a pre-run phase by perfusing the cells for $5 \mathrm{~min}$ with standard Tyrode's solution (composed of $\mathrm{NaCl}$, $135 \mathrm{mM}$; KCl, $4 \mathrm{mM}$; $\mathrm{CaCl}_{2}, 1.8 \mathrm{mM} ; \mathrm{MgCl}_{2}, 1 \mathrm{mM}$; glucose, $11 \mathrm{mM}$; and Hepes, $2 \mathrm{mM}$; adjusted to $\mathrm{pH}$ 7.2 with $\mathrm{NaOH}$ ). In control experiments, cells were exposed at regular intervals (every $250 \mathrm{sec}$, for $100 \mathrm{sec})$ to Tyrode's solution containing ATP $(1 \mu \mathrm{M}$, repeated four times). Between the ATP incubations, cells were perfused with Tyrode's solution. In test experiments, the L2 cells were superfused alternately with Tyrode's solution containing ATP $(1 \mu \mathrm{M})$ or with Tyrode's solution containing a combination of ATP $(1 \mu \mathrm{M})$ with neopterin $(100 \mathrm{nM})$.

\section{Reagents}

DMEM with and without phenol red, FCS, L-glutamine, penicillin-streptomycin, and trypsinEDTA was purchased from Gibco Life Technology (Eggenstein, Germany). Neopterin was purchased from Schircks Lab. (Jona, Switzerland). All other chemicals were from Sigma Chemicals (Deisenhofen, Germany). 

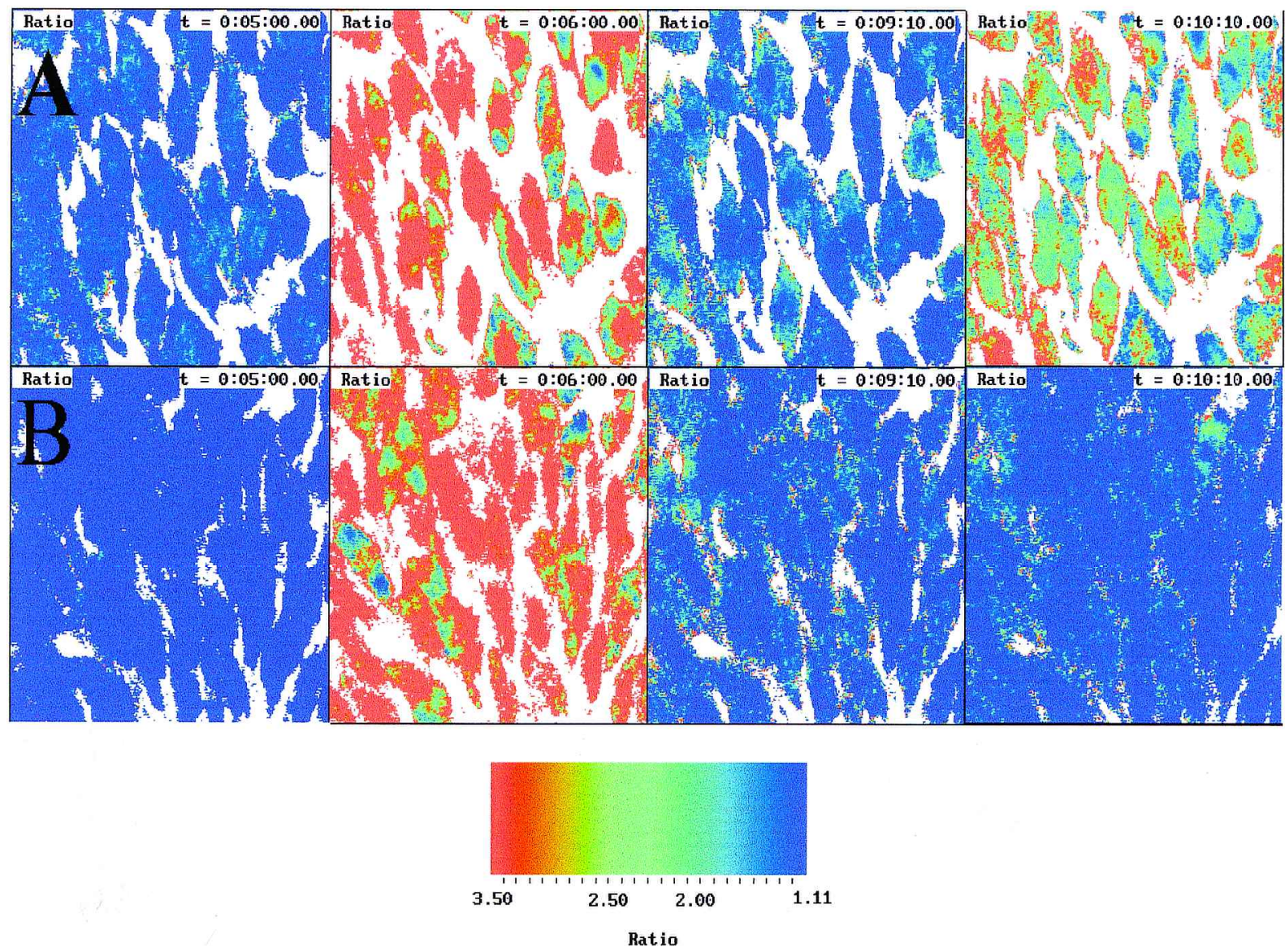

FIG. 2. Pseudocolor images of the $\mathrm{Ca}^{2+}$ distribution in $\mathrm{L} 2$ cells at different stages of experiments. (a) The upper row of images was taken during an experiment with two consecutive ATP stimulations. In Tyrode's solution, $\left[\mathrm{Ca}^{2+}\right]_{\mathrm{i}}$ in the cells is low $(t=$ 00:05:00). After a stimulation with ATP, $\left[\mathrm{Ca}^{2+}\right]_{i}$ rises in nearly all cells $(t=00: 06: 00)$. During the washout, $\left[\mathrm{Ca}^{2+}\right]_{i}$ returns to baseline level $(t=00: 09: 10)$. A second stimulation with ATP elicits an increase in $\left[\mathrm{Ca}^{2+}\right]_{\mathrm{i}}$ again $(t=00: 10: 10)$. (b) In the lower row of images, an experiment is exhibited during which the cells were stimulated with ATP or with ATP and neopterin, alternately. After the expected increase in $\left[\mathrm{Ca}^{2+}\right]_{\mathrm{i}}$ following a stimulation with ATP $(t=00: 06: 00)$, the simultaneous application of ATP and neopterin did not induce a change in $\left[\mathrm{Ca}^{2+}\right]_{i}(t=00: 10: 10)$.

\section{Statistical analysis}

For further analyses, those cells that exhibited sufficient fluorescence at the end of the experiment were selected. On each of these cells, an average ratio value was calculated in a representative part. This was plotted as a function of time. For standardization, the first 10 ratio values were averaged and set to $100 \%$. All ratio values were brought into relation with this reference value. By this procedure, ratio changes are transferred to percent changes. Thus, under control conditions, each cell starts with values near $100 \%$. At each time point, the percent values of all cells were averaged and their standard deviations (SD) were calculated. Significance of differences was calculated by analysis of variance followed by Tukey's post test. $p<0.05$ was considered significant.

\section{Results}

L2 cells stimulated with $1 \mu \mathrm{M}$ of ATP develop $\left[\mathrm{Ca}^{2+}\right]_{\mathrm{i}}$ transients (i.e. $\left[\mathrm{Ca}^{2+}\right]_{\mathrm{i}}$ increases and returns to control levels in the presence of ATP after about $3 \mathrm{~min}$ ) (Fig. 2a), as indicated by the change in color. During the washout phase in Tyrode's solution, $\left[\mathrm{Ca}^{2+}\right]_{i}$ returned to baseline values. This procedure was repeated three times with ATP causing a rise in $\left[\mathrm{Ca}^{2+}\right]_{i}$ each time; however, with a decreasing amplitude. This incubation protocol has been applied to a total of approximately 200 different cells in nine independent runs.

Figure $2 \mathrm{~b}$ shows a representative result of the corresponding incubations according to the second experimental protocol where cells were exposed to either ATP or ATP with neopterin alternately. In comparison with the first protocol, there was a pronounced increase in $\left[\mathrm{Ca}^{2+}\right]_{i}$ after the first stimulation with ATP. The second ATP pulse was performed in the presence of neopterin $(100 \mathrm{nM})$. This time, a change in fluorescence ratio could not be detected, indicating a stable $\left[\mathrm{Ca}^{2+}\right]_{\mathrm{i}}$. However, after a washout phase, cells reacted again to stimulation with ATP. As a repetition of the second incubation, the fourth incubation was performed with ATP $(1 \mu \mathrm{M})$ and neopterin $(100 \mathrm{nM})$. Again, $\left[\mathrm{Ca}^{2+}\right]_{\mathrm{i}} \mathrm{did}$ not respond to 

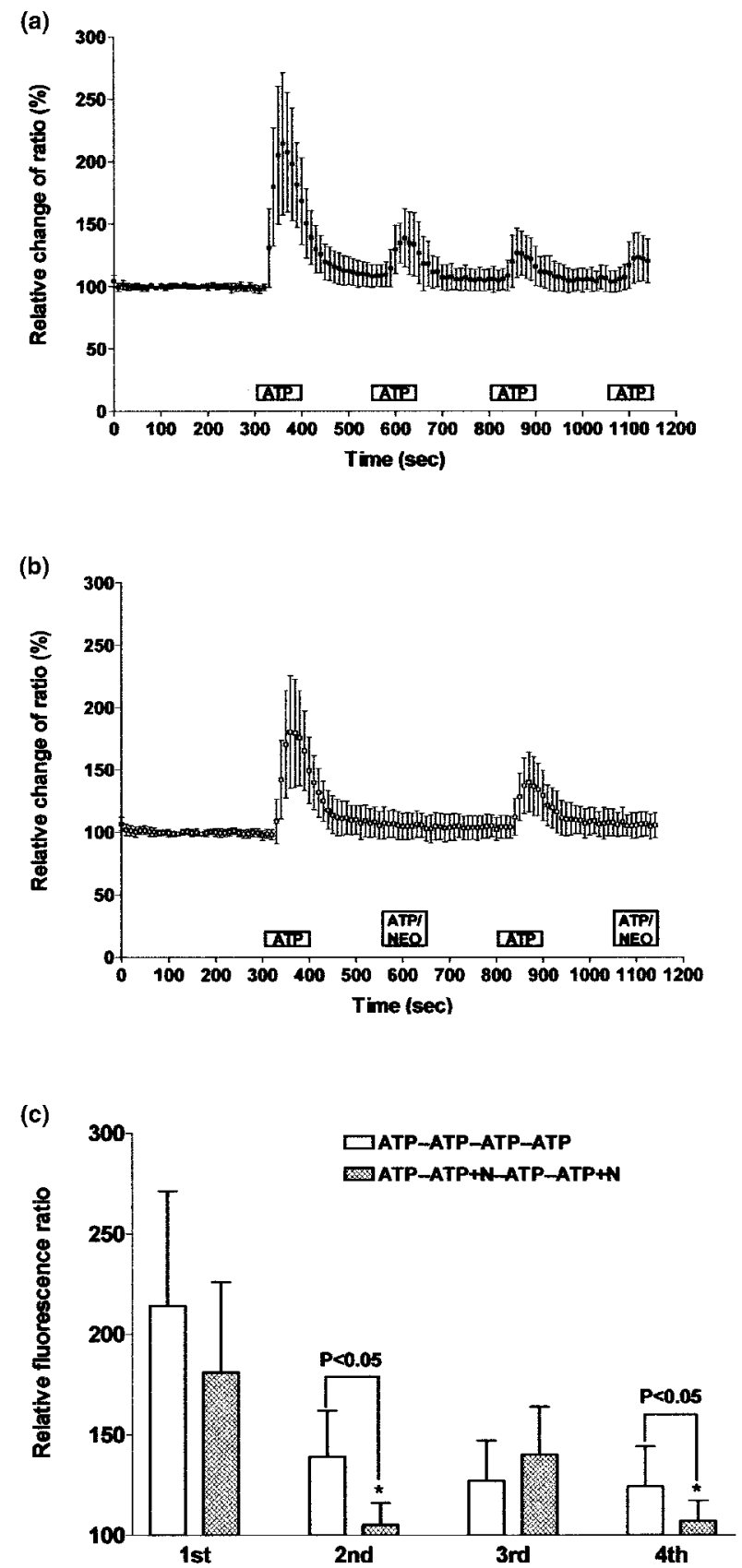

FIG. 3. Averaged time courses of relative change of $\left[\mathrm{Ca}^{2+}\right]_{i}$. (a) Each of four consecutive applications of ATP induces an increase in $\left[\mathrm{Ca}^{2+}\right]_{i}$. Data are presented as mean \pm SD of cells. (b) Application of ATP induces an increase in $\left[\mathrm{Ca}^{2+}\right]_{\mathrm{i}}$, whereas simultaneous application of ATP and neopterin (NEO) fails to change $\left[\mathrm{Ca}^{2+}\right]_{\mathrm{i}}$. Data are presented as mean \pm SD of 200 cells. (c) Comparison of maximal changes in fluorescence ratio for both the first (open bars) and the second (hatched bars) experimental protocols. 1st, ATP versus ATP; 2nd, ATP versus ATP + neopterin (N); 3rd, ATP versus ATP; 4th, ATP versus ATP + neopterin. * Significant differences.

the stimulation. Similar to the first experimental protocol (Fig. 2a), a total of nine different cell layers with approximately 200 individual cells were investigated.

Figure 3 summarizes the results of the statistical analyses performed with the digitized fluorescence ratio images. Figure 3 a shows the changes in relative fluorescence ratio as observed in $\mathrm{L} 2$ cells subjected to the first experimental protocol. All four applications of ATP led to a significant increase in fluorescence ratio, and thus a rise in $\left[\mathrm{Ca}^{2+}\right]_{\mathrm{i}}$. In Fig. $3 \mathrm{~b}$, the results of the second experimental protocol are demonstrated. Again, the addition of ATP resulted in an increased $\left[\mathrm{Ca}^{2+}\right]_{\mathrm{i}}$. There is no detectable change of fluorescence ratio when cells were exposed to the combination of ATP and neopterin for the first time. This was not due to an inability of the cells to increase $\left[\mathrm{Ca}^{2+}\right]_{i}$ because a consecutive application of ATP alone led to an increase in fluorescence ratio again.

The maximal changes in relative fluorescence ratio of the first incubation procedure were compared with the corresponding data from the second experimental protocol (Fig. 3c). Both ATP-induced $\mathrm{Ca}^{2+}$ transients observed in the first incubation procedure (first step, $214 \pm 57 \%$; third step, $127 \pm 20 \%$ ) did not differ significantly from the respective ratios of the second set-up (first step, $181 \pm 45 \%$; third step, $140 \pm 24 \%$ ). However, addition of neopterin to ATP inhibited the intracellular $\mathrm{Ca}^{2+}$ transients significantly (in the second step, from $139 \pm 23 \%$ to $105 \pm 11 \%, p<0.001$; in the fourth step, from $124 \pm 20 \%$ to $107 \pm 10 \%, p<$ 0.001).

\section{Discussion}

In summary, the present study demonstrates that neopterin inhibits ATP-induced $\mathrm{Ca}^{2+}$ transients in the type II-like alveolar epithelial cell line L2. ATP has been shown to be a potent stimulus for surfactant release in type II cells. ${ }^{11} \mathrm{~A}$ role of $\mathrm{Ca}^{2+}$ in the secretion of surfactant proteins was suggested by the use of $\mathrm{Ca}^{2+}$ ionophores. ${ }^{5}$ Considering the fact that ATP evoked a high $\mathrm{Ca}^{2+}$ release in many studies, ${ }^{9,10}$ one may speculate that $\left[\mathrm{Ca}^{2+}\right]_{i}$ is a supportive step for ATP-induced surfactant release. Among the potential mechanisms mediating the effects of ATP on intracellular $\mathrm{Ca}^{2+}$ is the activation of L-type voltagedependent $\mathrm{Ca}^{2+}$ channels, as reported for $\mathrm{L} 2$ cells by Dietl et al. ${ }^{6}$ In addition, $\mathrm{Ca}^{2+}$ oscillations in primary cultures of airway epithelial cells promoted by ATP have been demonstrated to be due to P2U purinoceptor stimulation and to the continuous production of inositol-1,4,5-triphosphate $\left(\mathrm{IP}_{3}\right) .{ }^{12}$ The inhibitory capacity of oxidative stress on the ion permeability of voltage-sensitive $\mathrm{Ca}^{2+}$ channels has been demonstrated. $^{7,8}$ In various other cell lines, oxidative stress suppressed the activation of $\mathrm{IP}_{3}$ induced by both hormonal and non-hormonal stimuli. ${ }^{12,13}$ Concerning L2 cells, exogenous nitric oxide donors, which represent another source of reactive oxygen species (ROS), have been shown to inhibit spontaneous depolarizations by L-type $\mathrm{Ca}^{2+}$ currents. ${ }^{14}$ It has been proposed that pteridine compounds act by the modulation of oxygen 
radical-mediated processes (e.g. by activating the ROS-sensitive transcription factor NF- $\mathrm{B}) .{ }^{3}$ The activation of NF- $\mathrm{B}$ could be prevented by application of anti-oxidants. This may provide an explanation for the stimulatory effects of neopterin on gene expression of inducible nitric oxide synthase or tumor necrosis factor- $\alpha .^{3,15}$ Taken together, these data imply that neopterin may not only affect $\mathrm{Ca}^{2+}$ transients in alveolar epithelial cells via short-term mediated oxidative stress. Furthermore, long-term interactions between neopterin and various other mediators of the inflammatory system (e.g. activation of nitric oxide synthases with the subsequent production of nitric oxide) may result in prolonged suppression of $\mathrm{Ca}^{2+}$-dependent processes.

According to our knowledge, only one investigation has been performed to date dealing with the effects of neopterin on intracellular $\mathrm{Ca}^{2+} \cdot{ }^{16}$ Most interestingly, the data of Wöll et al. are contradictory to our observations, since they found an increase in $\left[\mathrm{Ca}^{2+}\right]_{\mathrm{i}}$ in the human myelomonocytic cell line THP-1 in the presence of neopterin. These results suggest that neopterin interferes with $\left[\mathrm{Ca}^{2+}\right]_{i}$ in a cell type-specific manner. In the case of monocytes, $\mathrm{Ca}^{2+}$ increases have been shown to play an important role in the activation of these cells, with the stimulation of NADPH oxidase being, at least in part, dependent on an elevation of $\left[\mathrm{Ca}^{2+}\right]_{\mathrm{i}} \cdot{ }^{17}$ It is tempting to speculate that neopterininduced $\mathrm{Ca}^{2+}$ transients in immune cells contributes to the process of respiratory burst, while in non-immune cells (e.g. alveolar epithelium) neopterin exerts an inhibitory effect on intracellular $\mathrm{Ca}^{2+}$.

Considering inflammatory disorders within the pulmonary system (e.g. sarcoidosis, lung cancer, tuberculosis, adult respiratory distress syndrome, ARDS), the severity as well as the outcome of the disease was found to be correlated with an increase in serum neopterin levels up to $\sim 150 \mathrm{nM} .{ }^{1}$ Thus, the neopterin concentration of $100 \mathrm{nM}$ applied in this study is representative for inflammatory diseases of the lung. A decreased production and release of surfactant proteins is observed frequently in these situations. By inhibition of $\mathrm{Ca}^{2+}$ transients in type II alveolar epithelial cells, neopterin may contribute to this detrimental process, thereby representing an important mediator of the damage and dysfunction of the airway epithelium during lung inflammation.
ACKNOWLEDGEMENTS. The authors would like to thank Ms H. Bock, Ms G. Conrad, Ms M. Schloesser, and Ms M. Czechowski for their expert technical assistance.

\section{References}

1. Fuchs D, Weiss G, Reibnegger G, Wachter H. The role of neopterin as a monitor of cellular immune activation in transplantation, inflammatory, infectious, and malignant diseases. Crit Rev Clin Lab Sci 1992; 29: 307-341.

2. Murr C, Fuchs D, Gossler W, et al. Enhancement of hydrogen peroxideinduced luminol-dependent chemiluminescence by neopterin depends on the presence of iron chelator complexes. FEBS Lett 1994; 338: 223-226

3. Hoffmann G, Schobersberger W, Frede S, et al. Neopterin activates transcription factor nuclear factor-kappa B in vascular smooth muscle cells. FEBS Lett 1996; 391: 181-184.

4. Hoffmann G, Kenn S, Wirleitner B, et al. Neopterin induces nitric oxidedependent apoptosis in rat vascular smooth muscle cells. Immunobiology 1998; 199: 63-73.

5. Sano K, Voelker DR, Mason RJ. Effect of secretagogues on cytoplasmic free calcium in alveolar type II epithelial cells. Am J Physiol 1987; 253: C679-C686.

6. Dietl P, Haller T, Wirleitner B, Volkl H, Friedrich F, Striessnig J. Activation of L-type $\mathrm{Ca} 2+$ channels after purinoceptor stimulation by ATP in an alveolar epithelial cell (L2). Am J Physiol 1995; 269: L873-L883.

7. Agostinho P, Duarte CB, Carvalho AP, Oliveira CR. Oxidative stress affects the selective ion permeability of voltage-sensitive $\mathrm{Ca} 2+$ channels in cultured retinal cells. Neurosci Res 1997; 27: 323-334.

8. Hammerschmidt $S$, Wahn $\mathrm{H}$. The effect of the oxidant hypochlorous acid on the L-type calcium current in isolated ventricular cardiomyocytes. $J$ Mol Cell Cardiol 1998; 30: 1855-1867.

9. Dorn CC, Rice WR, Singleton FM. Calcium mobilization and response recovery following $\mathrm{P} 2$-purinoceptor stimulation of rat isolated alveolar type II cells. Br J Pharmacol 1989; 97: 163-170.

10. Rice WR, Singleton FM. P2Y-purinoceptor regulation of surfactant secretion from rat isolated alveolar type II cells is associated with mobilization of intracellular calcium. $\mathrm{Br} J$ Pharmacol 1987; 91: $833-838$.

11. Gobran LI, Xu ZX, Lu Z, Rooney SA. P2u purinoceptor stimulation of surfactant secretion coupled to phosphatidylcholine hydrolysis in type II cells. Am J Physiol 1994; 267: L625-L633.

12. Evans JH, Sanderson MJ. Intracellular calcium oscillations induced by ATP in airway epithelial cells. Am J Pbysiol 1999; 277: L30-L41.

13. Fowler CJ, Tiger G. The sulphydryl oxidizing reagent diamide affects phosphoinositide-mediated signal transduction: implications for the pathogenesis of Alzheimer's disease. Cell Signal 1998; 10: 399-406.

14. Schobersberger W, Friedrich F, Hoffmann G, Volkl H, Dietl P. Nitric oxide donors inhibit spontaneous depolarizations by L-type $\mathrm{Ca}^{2+}$ currents in alveolar epithelial cells. Am J Physiol 1997; 272: L1092-L1097.

15. Hoffmann G, Frede S, Kenn S, et al. Neopterin-induced tumor necrosis factor-alpha synthesis in vascular smooth muscle cells in vitro. Int Arch Allergy Immunol 1998; 116: 240-245.

16. Wöll E, Weiss G, Fuchs D, Lang F, Wachter H. Effect of pteridine derivatives on intracellular calcium concentration in human monocytic cells. FEBS Lett 1993; 318: 249-252.

17. Kitagawa S, Ohsaka A, Yuo A, Takaku F, Saito M. The respiratory burst of granulocytes: modulation by inflammatory mediators and its mechanism. Tokai J Exp Clin Med 1988; 13: 299-305.

Received 2 January 2002

Accepted 25 February 2002 


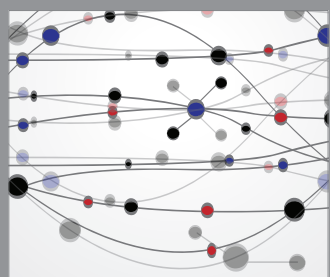

The Scientific World Journal
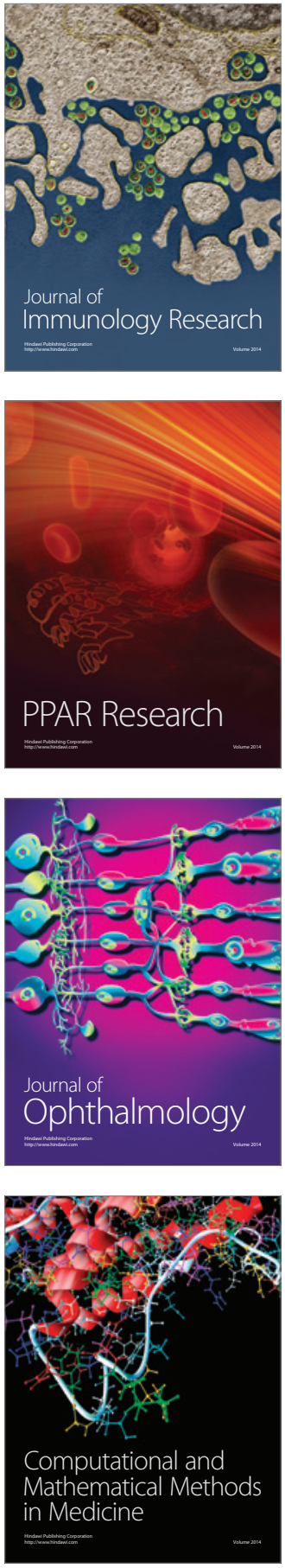

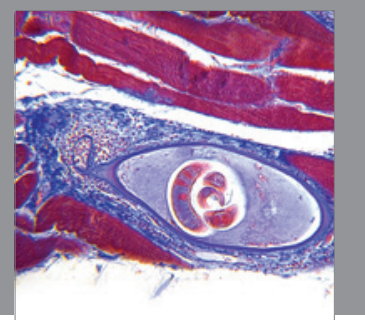

Gastroenterology

Research and Practice
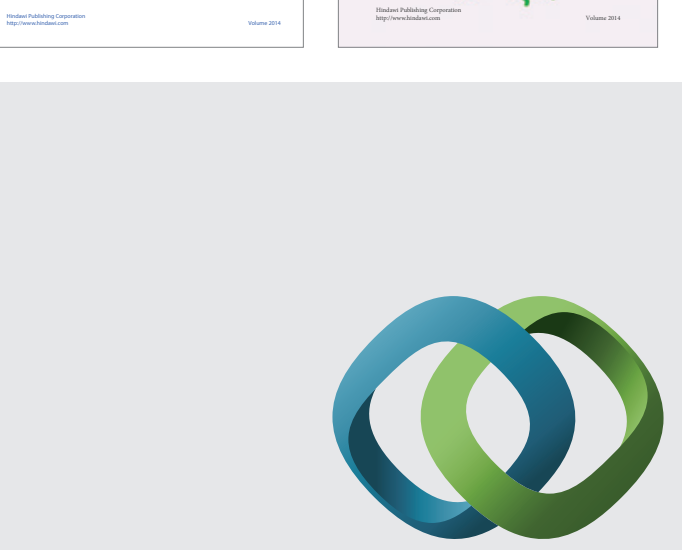

\section{Hindawi}

Submit your manuscripts at

http://www.hindawi.com
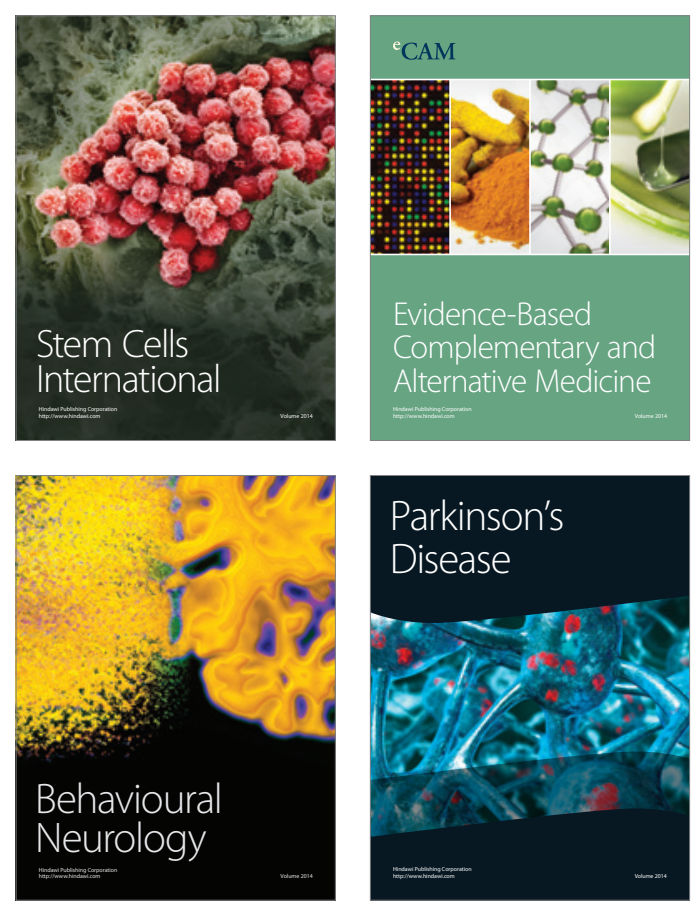

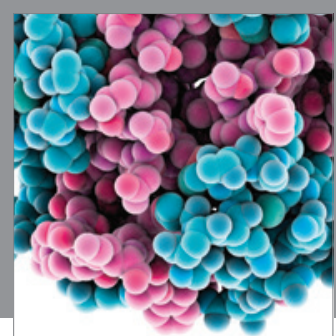

Journal of
Diabetes Research

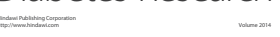

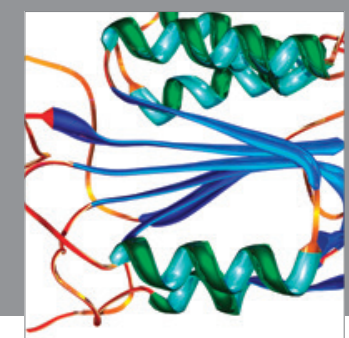

Disease Markers
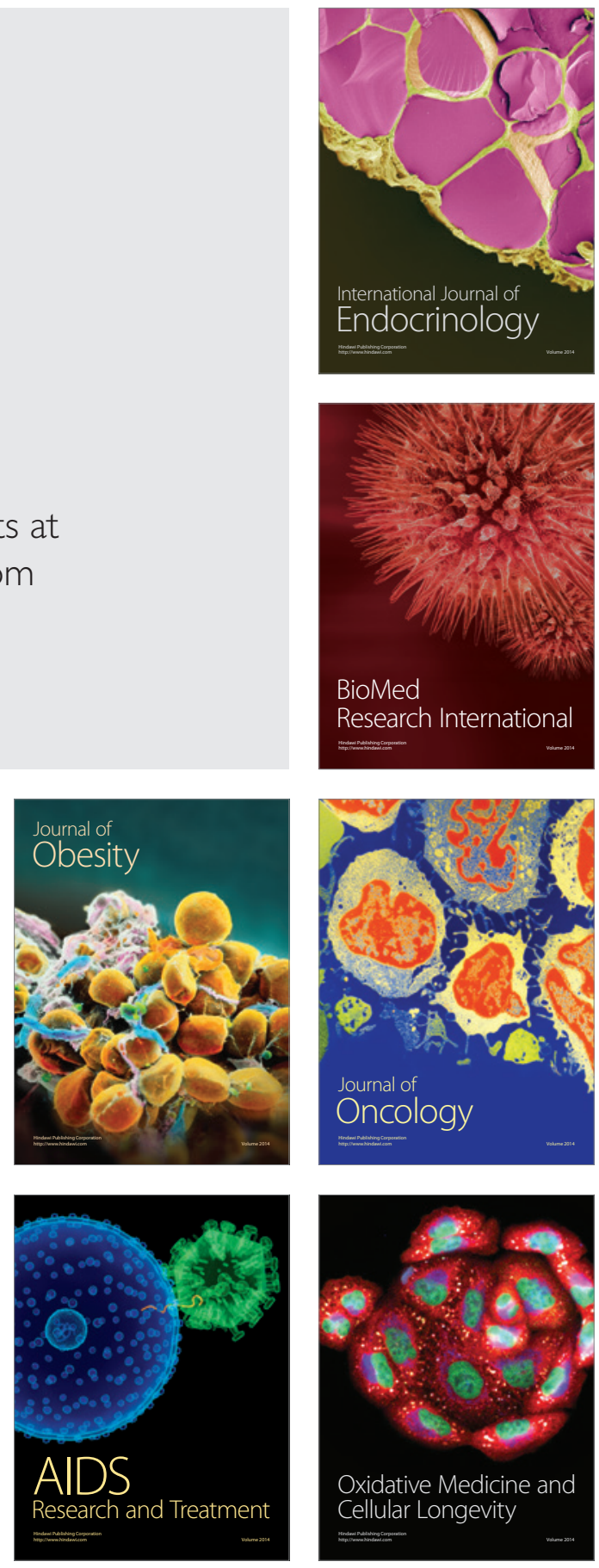